\title{
Development and Quality Analysis of Protein Enriched Instant Soup Mix
}

\author{
Monirul Islam1,2, Md Nazirul Islam Sarker ${ }^{3}$, Md Shahidul Islam $^{4}$, Adhita Sri Prabakusuma ${ }^{5}$ \\ Niaz Mahmud6, Yang Fang1, Peipei Yu1, Wenshui Xia1*
}

\author{
${ }^{1}$ State Key Laboratory of Food Science and Technology, School of Food Science and Technology, Jiangnan University, Wuxi, China \\ ${ }^{2}$ Rural Development Academy, Bogra, Bangladesh \\ ${ }^{3}$ School of Public Administration, Sichuan University, Chengdu, China \\ ${ }^{4}$ Department of Plant Pathology, Yunnan Agricultural University, Yunnan, China \\ ${ }^{5}$ Department of Food Technology, Universitas Ahmad Dahlan, Yogyakarta, Indonesia \\ ${ }^{6}$ Department of Nutrition and Food Technology, Jessore University of Science and Technology, Jessore, Bangladesh \\ Email: *xiaws@jiangnan.edu.cn
}

How to cite this paper: Islam, M., Sarker, Md.N.I., Islam, Md.S., Prabakusuma, A.S., Mahmud, N., Fang, Y., Yu, P.P. and Xia, W.S. (2018) Development and Quality Analysis of Protein Enriched Instant Soup Mix. Food and Nutrition Sciences, 9, 663-675. https://doi.org/10.4236/fns.2018.96050

Received: April 28, 2018

Accepted: June 16, 2018

Published: June 19, 2018

Copyright $\odot 2018$ by authors and Scientific Research Publishing Inc. This work is licensed under the Creative Commons Attribution International License (CC BY 4.0).

http://creativecommons.org/licenses/by/4.0/

\begin{abstract}
The aim of the study was to develop protein enriched instant fish soup mix and analysis of the quality of various conditions. The study used a mechanical dryer for maintaining a constant air flow and temperature at its drying and dehydration stage. Powder was made after drying. An appropriate composition was used as an indicator. Various compositions like 75\%,65\%, 55\% and $45 \%$ fish powder were used as formulation 0 , formulation 1, formulation 2 , and formulation 3 respectively. Then these were reconstituted by boiled water for soup mix preparation. The result indicated that mixer 2 was the best composition. The finding suggested that $55 \%$ fish powder mix is the best composition for protein enriched instant soup mix. It will help to produce the instant soup mix and an alternative source of various costly animal and plant protein as a value-added material.
\end{abstract}

\section{Keywords}

Instant Soup, Fish Powder, Value Addition, Vegetable Powder, Fish Soup

\section{Introduction}

Soup is a liquid which is prepared from vegetables, fish or meat using with water, juice or stock and some thickening agents and fall under heterogenous category of food. Usually there are two kinds of soups like thick soup and clear soup. Thick soups are prepared by mixing powder of cereal or pulse flour, cream and eggs [1]. On the other hand, clear soups are made from clear extracts of plant 
parts and animal which are edible. Instant soup is almost ready to eat and take less time to cook [2]. It has an important role for maintain nutrition of the people by covering a wide range of dried foods [3]. There is a big demand of dry soup mixes in the global market [4]. Generally commercial production of instant soup largely depends on the physiochemical and rheological properties at the time of preparation [5]. Actually, rheological characters deal with the deformation and flow of matter. As a result, rheological parameters are important to understand the behavior of the food structure during processing [6] [7]. Instant dry fish soup has a large stored life. There are millions of people who suffered from malnutrition in the world. Instant soup mix can be a great source of nutrition of them [7] [8]. The deficiency of the protein can be minimized by supplying instant fish soup since it can provide a mentionable amount of protein to the diet [9]. Now fish is using an important element for making many types of instant food by value addition [10]. Instant fish soup can be a great source of protein in fast food [11]. There are so many studies have already done on instant soup but a few studies on instant fish soup. The study is intended to fill the gap by exploring the finding related to instant fish soup mix. The aim of the study was to explore a formula of better instant fish soup mix, the impact of fish powder on the content and specification of soup mix as a complete instant food.

\section{Review of Related Literature}

Instant food is very popular in modern society. Soup is one of the top instant foods which people like so much with other fast food item. It is actually a part of modern daily life. Soup is very much convenient to eat. It is now fulfilling the consumer's social requirements [10]. Upadhyay et al. [12] conducted a research work on instant herbal mix soup from various vegetable like potato, carrot, tomatoes, garlic and others and found that leguminous elements increases sensory significantly with increasing nutritional advantages.

Usually there are two types of soups are available viz. clear and thick soups. Chandramouli et al. [13] conducted a study on soup powder preparation and nutritional status analysis. They used various ingredients like Moringa oleifera, Centellaasiatica, and Solanum trilobatum for their study. Basically, they used the dried leaves of these species and found that corn flour was a good thickening agent and sensory was increased due to coriander and pepper powder [14]. There are various types of soups are available in the market. Some soups are prepared from vegetables elements and some are from animal and fish elements. Instant soup helps to fulfill people's nutrient requirement quickly by taking less time [15]. Sudarsan et al. [9] reported that instant soup is almost free from pathogenic attack and it can preserve its quality until one month after preparation at normal condition. They used horse gram, onion and garlic powder, radish leaves, pepper and salt for their study and found that all the ingredients are good for making instant soup which can provide more nutritional supply than other soup [8]. The old aged people are increasing day by day. Instant soup mix may 
be a better nutritional supplement for them for meeting their dietary requirements. Satusap et al. [16] mentioned that instant soup which made from dried vegetables were good for older people. The food product which is available in the market may not be suitable for older people in terms of cost, low nutrition and physical characteristics [14]. So, instant soup is best for them.

Formulation food products are increasing day by day to meet the requirements of the consumers [15]. The formulation on value added products are now the main target of the consumers. Because it can supply the nutritional value as well as delicious test to consumers. Monteiro et al. [17] conducted a study on the instant soup which was made from Tilapia (Oreochromis niloticus) and concluded that instant Tilapia soup can be used in food industry on additive material on making new food item. Udari et al. [18] conducted a research on omega-3 containing soup powder and mentioned that instant soup is containing more omega-3 (9.31\%) than fried fish. They used some ingredients like fish powder, fish oil, tomato, milk powder, salt, vegetables and spices for their research.

Instant soup is a major element of instant food which is highly preferred food of modern society for simple, easy and instant preparation characteristics. Dhiman et al. [19] conducted a study on storage ability of pumpkin instant soup is about six months. They used some other additive ingredients like moong pulse, tomato, spices and condiment's powder, pea, spinach and carrot for their study. Generally, people of developing country are suffering from malnutrition [20]. Instant soup may be a potential source to meet the demand of nutritional requirements. Rahman et al. [21] conducted a study in Bangladesh on instant fish soup and concluded that the percent fish powder was the best composition other two composition. They used ingredients like tomato, sugar, spices, cauliflower and salt for their study. Legume is a good source of vitamins, minerals and dietary protein. Rokshana et al. [22] conducted a research work on development and storage quality of soup powder which was made from legume and vegetables and reported that the quality was as usual up to six months.

Fish by-products are usually thrown away due to its no usability in traditional practice. But it gets a due attention from scientific world from last two decades. Now analysis shows that fish by-product is a great source of oils, hydrolysates, collagen, bioactive peptides and gelatin. So, fish is a potential item in terms of low price, high availability, easy processing and good source of nutrition [23]. Literature survey shows that there are so many researches have already done but a very few researches are found on fish based instant soup mix. The piece of study was undertaken to address the research gap and considering importance of the subject matter.

\section{Materials and Methods}

\subsection{Components}

Silver Carp (average weight $2.5 \mathrm{~kg} /$ fish) fishes were purchased from local aquatic products market of Wuxi city, Jiangsu province, China. Soybean, fresh tomato, 
zinger, garlic and dried spices and other raw materials were purchased locally from super shop of the same city. Chemicals and equipment were used from ready stocks of food processing technology laboratory of Jiangnan University, Wuxi, China. All chemicals used were of the analytical reagent grade [21].

\subsection{Preparation of Fish Powder}

Collected fresh was tested organoleptically. Meat of the fish was found translucent. Fishes were beheaded by knife and scales, fins, gills, viscera were removed. Then fishes were washed with $1 \%$ brine solution. After that fishes were submerged with $1 \%$ turmeric powder solution for 10 minutes. Then fishes were cooked at $100^{\circ} \mathrm{C}$ for $10 \mathrm{~min}$ with $2 \%$ vinegar and $1 \%$ sesame oil solution [24]. After separation of all bones, fish was dried in an oven at $60^{\circ} \mathrm{C}$ overnight till complete drying. For drying it was spread on flat tray at a thickness of thin layer. The dried fish was ground by electrical grounder then was packed in LDPE bag and storage at room temperature.

\subsection{Preparation of Tomato Powder}

For Tomato powder making, tomato was cut into slices and cooked. Pulp was dried in an oven dryer for 4 hours at $60^{\circ} \mathrm{C}$. Dried pulp was ground then was packed in LDPE bag and storage at room temperature.

\subsection{Preparation of Full Fat Soybean Powder}

Soybean powder was made little modification. Soybean seeds was wasted then soaked in water for 8 hours for removing the hulls. Then soybean seed was dried for $65^{\circ} \mathrm{C}$ in an oven [23]. After that soybean seed was roasted and ground by electrical grinder (made in China). The ground powder was packed in LDPE bag and storage at room temperature.

\subsection{Preparation of Garlic Powder}

Raw garlic was blanching by $100^{\circ} \mathrm{C}$ hot water for 5 minutes and dried by oven drying at $65^{\circ} \mathrm{C}$ for 6 hours [18]. Then dried clove of garlic was ground by electrical grounder. The ground powder was packed in LDPE bag and storage at room temperature.

\subsection{Preparation of Zinger Powder}

Raw zinger was blended by electric blender and dried by oven drying at $65^{\circ} \mathrm{C}$ for 6 hours in thin layer. Then dried zinger was ground by electrical grounder. The ground powder was packed in LDPE bag and storage at room temperature [17].

\subsection{Preparation of Spices Mix Powder}

Dried cinnamon $30 \%$, prickly ash $10 \%$, cumin $25 \%$, white pepper $10 \%$, white paper $10 \%$ and sesame $25 \%$ were mastered by electric balance and roasted [25]. Then spices were ground by electric grounder to make spices mix. The ground 
spices mix powder was packed in LDPE bag and storage at room temperature.

\subsection{Processing Yield Percentage}

The whole fish, tomato, zinger, garlic, spices mix and instant soup were weighed. The processing yield was calculated from weight of each final products multiplied by 100 and divided by the weight of their precursor product [26]. Three analytical replicates were performed for each treatment and mean value was calculated.

Processing yield $\%=$ Final products obtain $\times 100 /$ Raw weight of respective sample

\subsection{Formulation of Soup Mix Powder}

Four different formulations of soup mix were prepared by using different fish powder: soya powder ratios as given in Table 1. F0 was the control soup mix. Soup was prepared by re-constitution of instant soup mix with boiled water.

\subsection{Proximate Analysis}

Parameters of the proximate analysis (Moisture, Ash, Crude protein, Total carbohydrate and Energy) of the developed fish powder as well soup mix powder was analyzed [27].

\subsection{Sensory Evaluation}

The sensory assessment has been performed using the scoring test developed by Sudarsan et al. [9] ten panelists have been used to evaluate the sensory attributes of soup. The samples were blind-coded by special codes; the panelists were not informed about the experimental approach [1]. They were asked to give a score for each of color, appearance, odor, texture, taste and overall acceptability while the soup mix was prepared [19]. Then soup has been served to the panelists to complete the evaluation of the sensory attributes. The panelists were asked to wash their mouths with warm water between samples.

\subsection{Statistical Analysis}

The obtained data was statistically analyzed for analysis of variance (ANOVA) and consequently Duncan's Multiple Range Test (DMRT) has been used to

Table 1. Different formulation of powdered soup mix.

\begin{tabular}{cccccccccc}
\hline & \multicolumn{7}{c}{ Ingredients (\%) } \\
\cline { 2 - 9 } Formulation & $\begin{array}{c}\text { Fish } \\
\text { powder }\end{array}$ & $\begin{array}{c}\text { Soya } \\
\text { powder }\end{array}$ & $\begin{array}{c}\text { Tomato } \\
\text { powder }\end{array}$ & salt & Sugar & MSG & $\begin{array}{c}\text { Zinger } \\
\text { powder }\end{array}$ & $\begin{array}{c}\text { Garlic } \\
\text { powder }\end{array}$ & $\begin{array}{c}\text { Spices mix } \\
\text { powder }\end{array}$ \\
\hline F0 & 75 & 0 & 12 & 5 & 2 & 1 & 1 & 1 & 3 \\
F1 & 65 & 10 & 12 & 5 & 2 & 1 & 1 & 1 & 3 \\
F2 & 55 & 20 & 12 & 5 & 2 & 1 & 1 & 1 & 3 \\
F3 & 45 & 30 & 12 & 5 & 2 & 1 & 1 & 1 & 3 \\
\hline
\end{tabular}


determine significant difference [17] [28]. Data has been analyzed using the IBM SPSS software, version 20 at the $5 \%$ level of significance $(P=0.05)$.

\section{Results and Discussions}

\subsection{Composition of Fresh Fish and Dried Fish Powder}

The moisture content in fresh silver carp fish, mechanical dried fish powder was $76.7 \%$ and $7.78 \%$ respectively. The ash content in fresh fish $1.94 \%$ and that was in mechanical dried fish was $13.02 \%$. The fat content in fresh fish was $2.11 \%$ and that was in mechanical dried fish $14.96 \%$. The protein in fresh fish was $19.25 \%$ and that was in mechanical dried fish $64.24 \%$. Protein, fat, ash of dried sample was increased but moisture content of dried samples was decreased [1]. The higher concentration of nutrients in the dried product is due to lower moisture content. The chemical composition of fresh fish \& dried fish is given in the following Table 2.

\subsection{Composition of Instant Fish Soup Mix}

Among the three formulations Formulation No-2 was taken for analysis for its moisture, protein, fat, ash contents. The results are presented in Table 3. The moisture content in instant fish soup mix was $9.4 \%$. The ash, fat and protein content were found to be $15 \%, 1.39 \%$ and $9.4 \%$, respectively. The higher concentration of nutrients in the dried product was due to lower moisture content [23].

\subsection{Sensory Evaluation of Instant Fish Soup Mix}

The mean scores for color, texture, flavor and overall acceptability of three deferent amount of fish powder in Instant Fish Soup Mix are presented in Table 4.

The results expose that there are no significant variations in color which

Table 2. Composition of fresh and dried fish powder.

\begin{tabular}{ccc}
\hline Parameters & Fresh fish & Dried fish \\
\hline Moisture \% & 76.7 & 7.78 \\
Ash \% & 1.94 & 13.02 \\
Lipid (fat)\% & 2.11 & 14.96 \\
Protein \% & 19.25 & 64.24 \\
\hline
\end{tabular}

Table 3. The chemical composition of instant fish soup mix is given in the following.

\begin{tabular}{cc}
\hline Parameters & Soup mix formulation no $2(\operatorname{mix} 2)(55 \%$ fish powder $)$ \\
\hline Moisture \% & $9.5 \%$ \\
Ash \% & $15 \%$ \\
Lipid \% & $1.39 \%$ \\
Protein \% & $9.4 \%$ \\
Total Carbohydrate & $64.71 \%$ \\
\hline
\end{tabular}


found by a two-way analysis of variance (ANOVA) for taste preference (Table 4). The calculated value of $F$ test (7.9837) is greater than the tabulated value of $F$ test (3.89). This indicates the color of the samples of instant fish soup mixes were equally accepted and the numerical score varied from 2.40 to 4.99 (Figure 1). This denotes that the taste of different samples of soup mixes is not similarly acceptable (Table 4). As shown in Table 4 the flavor of Formulation-2 (55\% fish powder) is the most satisfactory among the samples and is followed by sample- 1 (65\% fish powder), while the lowest score is given by sample-3 (45\% fish powder).

The results explore that there are no significant variations in color which done by a two-way analysis of variance (ANOVA) for odor preference (Table 4) [29]. The calculated value of $\mathrm{F}$ test (1.2165) is smaller than the tabulated value of $\mathrm{F}$ test (3.89). It indicates the color of the samples of instant fish soup mixes were equally recognized and the numerical score varied from 2.70 to 4.45 (Figure 2).

The results discover that there are no significant variations in color which found by a two-way analysis of variance (ANOVA) for color preference (Table 4). The calculated value of $F$ test (0.1874) is lower than the tabulated value of $F$ test (3.89) [30]. It denotes the color of the samples of instant fish soup mixes are

Table 4. Means of sensory evaluation of instant fish soup mixes.

\begin{tabular}{|c|c|c|c|c|c|c|c|c|c|c|}
\hline \multirow{3}{*}{ Formulation } & \multicolumn{10}{|c|}{ Sensory characteristics } \\
\hline & \multicolumn{2}{|c|}{ Taste } & \multicolumn{2}{|c|}{ Odor } & \multicolumn{2}{|c|}{ Color } & \multicolumn{2}{|c|}{ Texture } & \multicolumn{2}{|c|}{$\begin{array}{c}\text { Overall } \\
\text { acceptance }\end{array}$} \\
\hline & Mean & Std & Mean & Std & Mean & Std & Mean & Std & Mean & Std \\
\hline 0 & $2.40 \mathrm{~b}$ & 0.50 & $2.70 \mathrm{~b}$ & 0.47 & $4.20 \mathrm{~b}$ & 0.41 & $4.25 \mathrm{~b}$ & 0.64 & $2.50 \mathrm{~b}$ & 0.51 \\
\hline 1 & $3.30 \mathrm{~b}$ & 0.46 & $3.10 \mathrm{~b}$ & 0.30 & $4.35 \mathrm{~b}$ & 0.48 & $4.40 \mathrm{~b}$ & 0.49 & $3.30 \mathrm{~b}$ & 0.46 \\
\hline 2 & $4.99 a$ & 0.03 & $4.45 \mathrm{a}$ & 0.51 & $4.40 \mathrm{a}$ & 0.50 & $4.45 \mathrm{a}$ & 0.51 & $4.45 \mathrm{a}$ & 0.51 \\
\hline 3 & $3.60 \mathrm{~b}$ & 0.68 & $3.80 \mathrm{~b}$ & 0.41 & $4.30 \mathrm{~b}$ & 0.47 & $4.10 \mathrm{~b}$ & 0.72 & $3.70 \mathrm{~b}$ & 0.66 \\
\hline
\end{tabular}

Note: The means with the same superscripts within a column are not significantly different at $\mathrm{p}<0.05$.

6

5

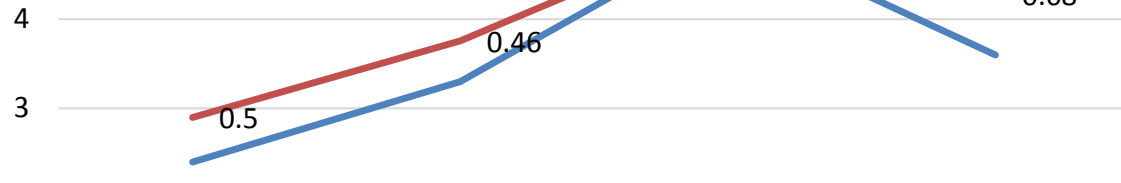

2

1

0

Figure 1. Showing the mean and standard deviation of taste of the sample. 


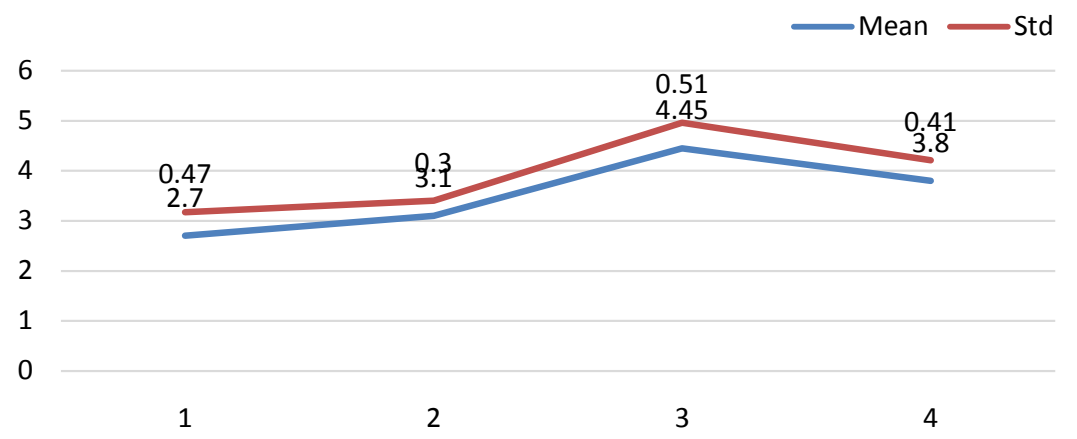

Figure 2. Showing the mean and standard deviation of odor of the sample.

equally accepted and the numerical score varies from 4.20 to 4.40 (Figure 3).

There is significant $(\mathrm{P}<0.05)$ difference in texture (Table 4$)$. The calculated value of $F$ test (5.9857) is greater than tabulated value of $F$ test (3.89). It mentions the texture of the samples of instant fish soup mixes are not equally accepted [31] and the numerical score varies from 4.10 to 4.45 (Figure 4).

It is apparent from the results of the ANOVA that there is a significant $(\mathrm{P}<$ $0.01)$ variation in general acceptability of the samples testes. The calculated value of $\mathrm{F}$ test (5.9371) is greater than tabulated F-value (3.89). As shown in Table 4 the results show that formulation- 2 has highest overall acceptability score among the samples tested and is followed by formulation- 3 while formulation- 0 got the lowest result [32]. Formulation-0 had the major part of (75\% fish powder) fish powder. Formulation-1, Formulation-2 and Formulation-3 (mix-1) bears 65\%, $55 \%$ and $45 \%$ fish respectively (Figure 5 ).

It is observed that Formulation-2 with 55\% fish secured the highest scores in all spheres and get first rank as "like very much" [26]. The second position gets by formulation-3 with $45 \%$ fish powder for all quality factors and is classified as "like moderately". Formulation-0 with $75 \%$ fish powder gets the lowest score among all factors and is classified as "like moderately". All the products are similarly acceptable in terms of color but different from one another in terms of flavor and texture [33]. Thus, flavor and texture are over influencing factors. The Figure 6 describes the particle size distribution of major samples.

The organoleptic taste test shows that soup sample with $55 \%$ fish powder gets the highest score in all aspect and is classified as "like very much" [34]. The soup with 55\% fish powder gets the second highest score for all characteristics and is classified as "like moderately" while the soup with $75 \%$ fish powder secured lowest score and is classified as "like moderately". The study clearly shows that fish flavor and texture are overriding factors influencing overall acceptability of soup from fish.

\subsection{Processing Yield Percentage}

It is observed that soybean powder is highest component in the processing yield. Spices mix powder followed the soybean powder among garlic powder, zinger powder, fish powder and tomato powder. The Figure 7 describes the major samples used in the research. 


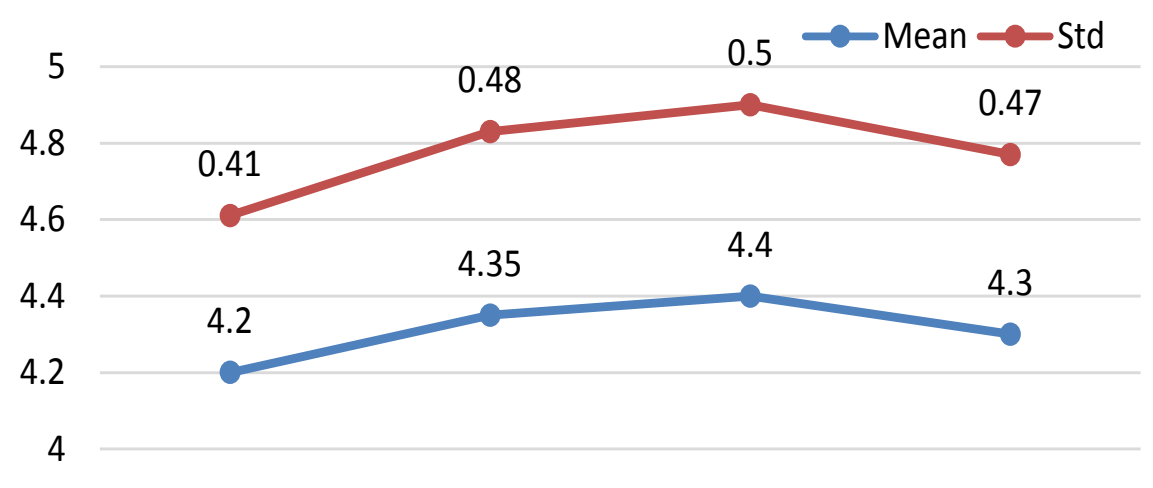

3.8

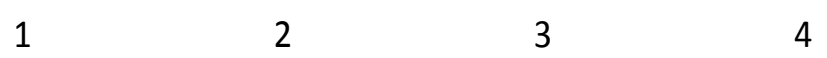

Figure 3. Showing the mean and standard deviation of color of the sample.

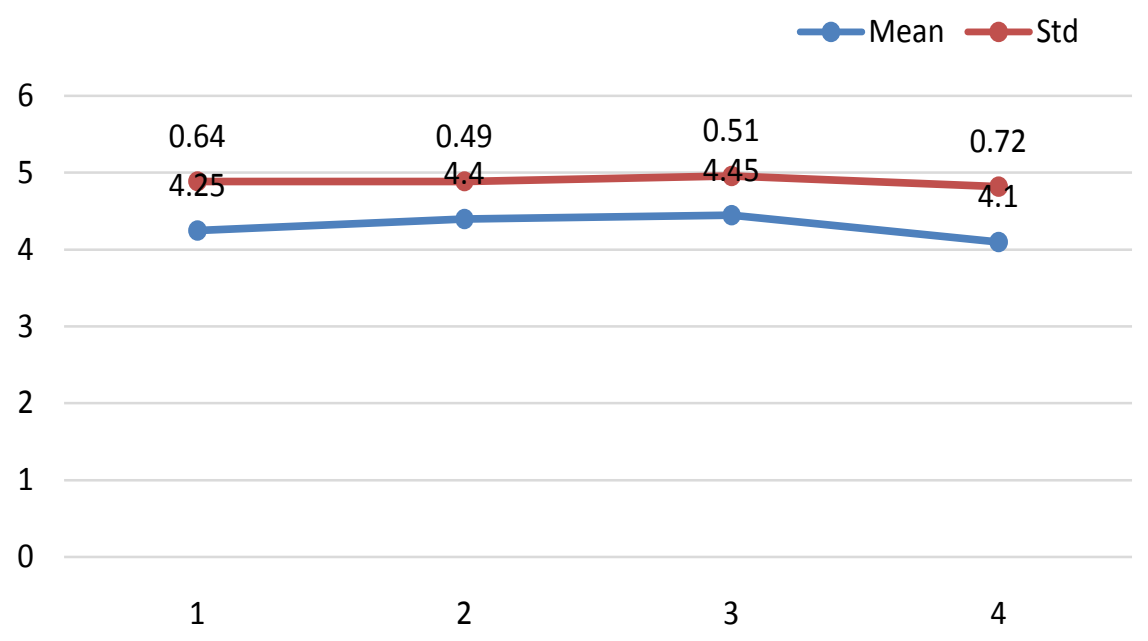

Figure 4. Showing the mean and standard deviation of texture of the sample.

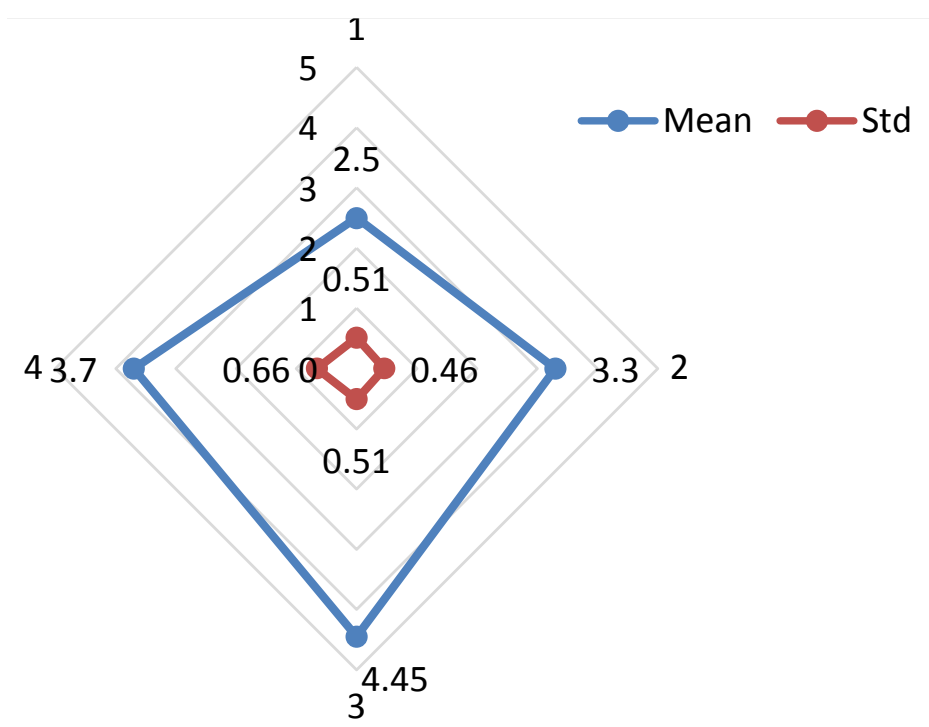

Figure 5. Showing the mean and standard deviation of overall acceptance of the sample. 


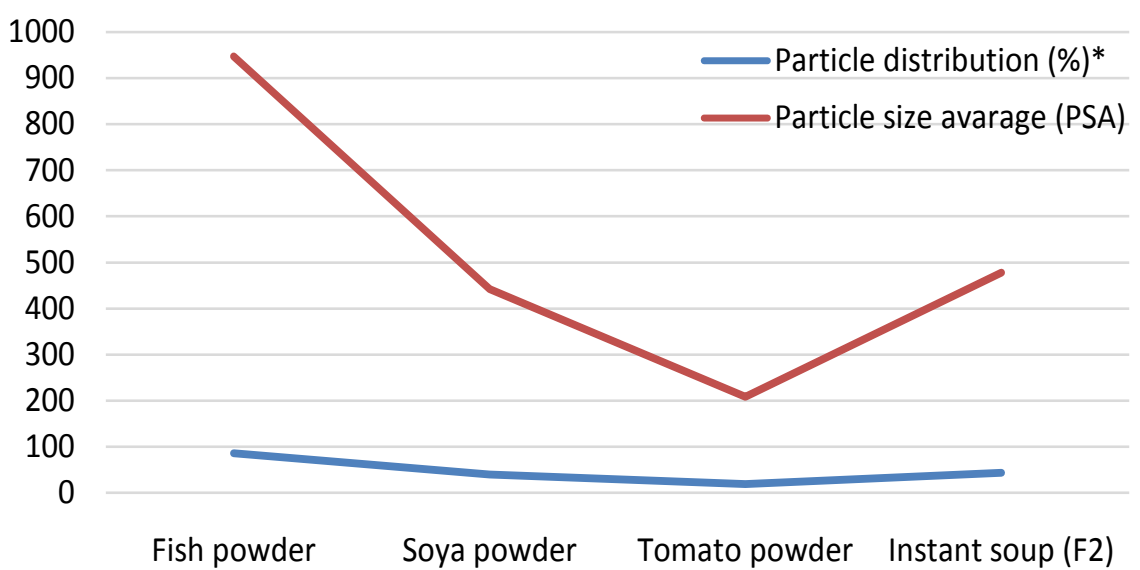

Figure 6. Showing the particle size distribution of the major samples.

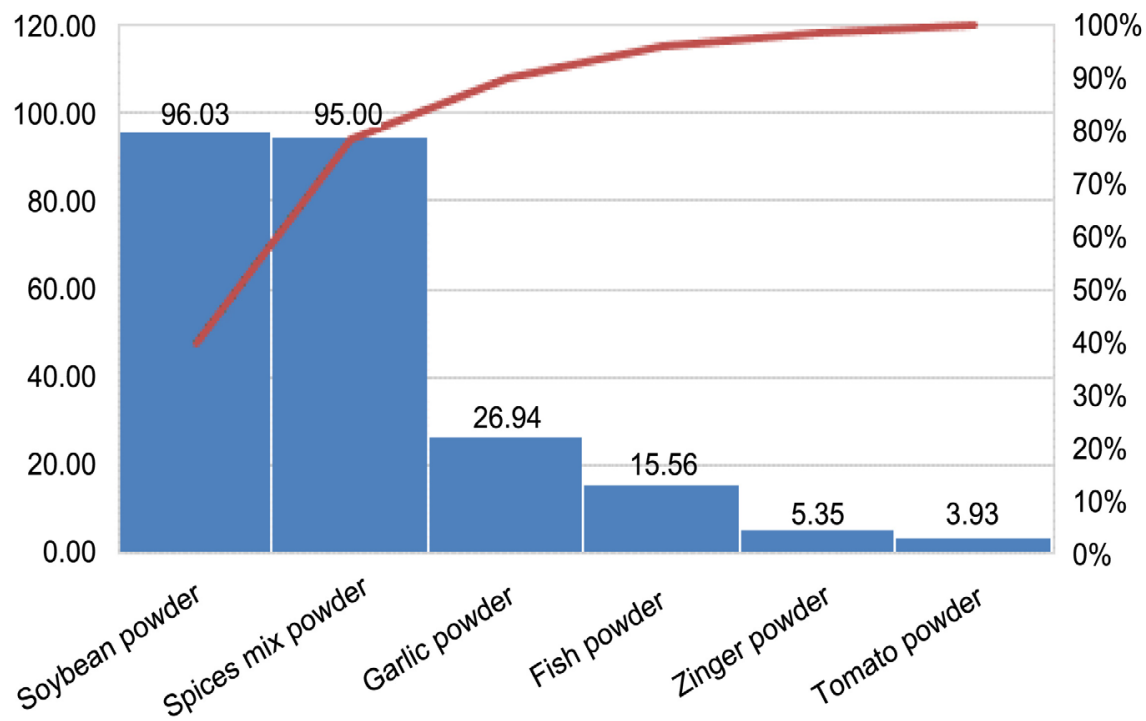

Figure 7. Showing processing yield percentage.

\section{Conclusion}

There is a great nutritiously and technologically potential in instant fish soup which especially made from silver carp. This study revealed that $55 \%$ fish powder mix is the best composition for protein enriched instant soup mix. This instant fish soup may be a great source of nutrition in fast food and alternative of some other animal and plant proteins as value added materials. It can be a good source of value added food for commercial processed food production. This study suggests that further study is needed to produce instant fish soup mix for a large scale commercial production as well as quality evaluation is also necessary for maintain protein enrichment.

\section{Acknowledgements}

This research was financially supported by the earmarked fund for China Agriculture Research System (CARS-45-26). Jiangsu Project for Fisheries (Y2017-30). 


\section{Conflict of Interest Declaration}

The authors declare no conflict of interest.

\section{References}

[1] Radha, C., Ogunsina, B.S and Hebina Babu, K.T. (2015) Some Quality and Micro-Structural Characteristics of Soup Enriched with Debittered Moringa Oleifera Seeds Flour. American Journal of Food Science and Technology, 3, 145-149.

[2] Karthika Devi, B., Kuriakose, S.P., Krishnan, A.V.C., Choudhary, P. and Rawson, A. (2016) Utilization of By-Product from Tomato Processing Industry for the Development of New Product. Journal of Food Processing \& Technology, 7, 608. https://doi.org/10.4172/2157-7110.1000608

[3] Sarker, M.N.I., Barman, S.C., Islam, M. and Islam, R. (2017) Role of Lemon (Citrus limon) Production on Livelihoods of Rural People in Bangladesh. Journal of Agricultural Economics and Rural Development, 2, 167-175.

[4] Li, W. and Savage, G.P. (2015) Oxalate Content of the Herb Good-King-Henry, Blitum Bonus-Henricus. Foods, 4, 140-147. https://doi.org/10.3390/foods4020140

[5] Abdel-Haleem, A.M.H. and Omran, A.A. (2014) Preparation of Dried Vegetarian Soup Supplemented with Some Legumes. Food and Nutrition Sciences, 5, 2274-2285. https://doi.org/10.4236/fns.2014.522241

[6] Abeysinghe, C.P. and Illeperuma, C.K. (2006) Formulation of an MSG (Monosodium Glutamate) Free Instant Vegetable Soup Mix. Journal of the National Science Foundation of Sri Lanka, 34, 91-95. https://doi.org/10.4038/jnsfsr.v34i2.2087

[7] Sarker, M.N.I. (2016) Causes and Possible Solutions of Seasonal Food Insecurity (Monga) Perceived by Char Dwellers in Bangladesh. International Journal of Ecology and Development Research, 1, 2-9.

[8] Sarker, M.N.I., Ali, M.A. and Islam, M.S. (2015) Causes and Possible Solutions of Poverty Perceived by Char Dwellers in Bangladesh. International Journal of Natural and Social Sciences, 2, 37-41.

[9] Sudarsan, S.M., Santhanam, S.G. and Visalachi, V. (2017) Development and Formulation of Instant Soup Mix from Sprouted Horse Gram and Radish Leaves. International Journal of Home Science, 3, 346-349.

[10] Sarker, M.N.I. (2016) Poverty of Island Char Dwellers in Bangladesh. Diplomica Publishing GmbH, Hamburg.

[11] Gokulakrishnan, P. (2014) Development and Quality Evaluation of Spent Hen Meat Powder and Its Utilization in Convenience Meat Products. Indian Veterinary Research Institute, Izatnagar.

[12] Upadhyay, S., Tiwari, R., Kumar, S. and Kohli, D. (2017) Production and Evaluation of Instant Herbal Mix Soup. International Journal of Agricultural Science and Research, 7, 37-42.

[13] Chandramouli, P., Bharathi, V.S.D., Sivakami, A., et al. (2012) Standardisation and Nutritional Analysis of Soup Powder Prepared from Moringa oleifera, Solanum trilobatum, Centella asiatica. International Journal of Future Biotechnology, 1, 1-20.

[14] Sarker, M.N.I. (2016) Knowledge, Adoption and Constraint Analysis of Chilli Technology in Char Area of Bangladesh. International Journal of Ecology and Development Research, 1, 16-18.

[15] Prodhan, A.S., Sarker, M.N.I., Sultana, A. and Islam, M.S. (2017) Knowledge, Adoption and Attitude on Banana Cultivation Technology of the Banana Growers of 
Bangladesh. International Journal of Horticultural Science and Ornamental Plants, 3, 47-52.

[16] Satusap, P., Chavasit, V., Kriengsinyos, W. and Judprasong, K. (2014) Development of Cereal and Legume Based Food Products for the Elderly. Springerplus, 3, 1-8. https://doi.org/10.1186/2193-1801-3-451

[17] Monteiro, M.L.G., Mársico, E.T., Lázaro, C.A., et al. (2014) Flours and Instant Soup from Tilapia Wastes as Healthy Alternatives to the Food Industry. Food Science and Technology Research, 20, 571-581. https://doi.org/10.3136/fstr.20.571

[18] Udari, A., Wickramasinghe, I. and Attygalle, M. (2015) Development of an Omega 3 Enriched Instant Soup Powder from Sardinella Longiceps. International Journal of Engineering Sciences \& Research Technology, 4, 644-652.

[19] Dhiman, A.K., Vidiya, N., Surekha, A. and Preethi, R. (2001) Studies on Development and Storage Stability of Instant Vegetable Pulav Mix. Journal of Food Science and Technology, 38, 231-234.

[20] Sarker, M.N.I., Bingxin, Y., Sultana, A. and Prodhan, A.S. (2017) Problems and Challenges of Public Administration in Bangladesh: Pathway to Sustainable Development. International Journal of Public Administration and Policy Research, 3, 16-25.

[21] Rahman, M.A., Saifullah, M. and Islam, M.N. (2012) Fish Powder in Instant Fish Soup Mix. Journal of the Bangladesh Agricultural University, 10, 145-148. https://doi.org/10.3329/jbau.v10i1.12106

[22] Rokhsana, F., Yeasmin, R. and Nahar, A. (2008) Studies on the Development and Storage Stability of Legume and Vegetable Based Soup Powder. Bangladesh Journal of Agricultural Research, 32, 451-459.

[23] Ishak, N.H. and Sarbon, N.M. (2018) A Review of Protein Hydrolysates and Bioactive Peptides Deriving from Wastes Generated by Fish Processing. Food and Bioprocess Technology, 11, 2-16. https://doi.org/10.1007/s11947-017-1940-1

[24] Farzana, T., Mohajan, S., Saha, T. and Hossain, M.N. (2016) Development of a Healthy Soup Powder Using Phytonutrient Enriched Mushroom-Moringa Leaf. DIU Journal of Allied Health Sciences, 3, 33-40.

[25] Farzana, T., Mohajan, S., Saha, T., et al. (2017) Formulation and Nutritional Evaluation of a Healthy Vegetable Soup Powder Supplemented with Soy Flour, Mushroom, and Moringa Leaf. Food Science \& Nutrition, 5, 911-920. https://doi.org/10.1002/fsn3.476

[26] Mogra, R. and Choudhry, M. (2014) Development and Quality Evaluation of Value Added Instant Rab Mixes. Journal of Food Science and Technology, 51, 1140-1146. https://doi.org/10.1007/s13197-012-0615-1

[27] Convenience I (2011) Characterization of Instant Soup Mix. 158-197.

[28] Sarker, M.N.I., Islam Ali, A.M., Islam, S.M. and Bari, A.M. (2016) Feeding Behavior and Food Preference of Red Pumpkin Beetle, Aulacophora Foveicollis. American Journal of Plant Biology, 1, 13-17.

[29] Kitsawad, K. and Tuntisripreecha, N. (2016) Sensory Characterization of Instant Tom Yum Soup. KMUTNB: International Journal of Applied Science and Technology, 9, 145-152. https://doi.org/10.14416/j.ijast.2016.02.001

[30] Radermacher, D. (2008) Microbiological Specifications for Dry Soups and Bouillons, and Ingredients to Be Used for Dry Soups and Bouillons-New AIIBP Guidelines. Deutsche Lebensmittel-Rundschau: Zeitschrift für Lebensmittelkunde und Lebensmittelrecht, 104, 342-350. 
[31] Thilsted, S.H., James, D., Toppe, J., et al. (2013) Maximizing the Contribution of Fish to Human Nutrition. ICN2 2nd International Conference on Nutrition: Better Nutrition Better Lives, Rome, 19-21 November 2014, 16.

[32] Singh, Y. and Prasad, K. (2015) Sorption Isotherms Modeling Approach of Rice-Based Instant Soup Mix Stored under Controlled Temperature and Humidity. Cogent Food \& Agriculture, 1, 1-11.

[33] Chellaram, C., Anand, T.P., Praveen, M.M., et al. (2014) Self-Life Studies on an Underutilized Sea Food from Southeast Coast of India. APCBEE Procedia, 8, 114-118. https://doi.org/10.1016/j.apcbee.2014.03.011

[34] Benković, M. and Bauman, I. (2009) Flow Properties of Commercial Infant Formula Powders. World Academy of Science, Engineering and Technology, 54, 495-499. 